\title{
Eutrophization process in a system used for rearing the nile tilapia (Oreochromis niloticus), Sáo Paulo State, Brazil
}

\author{
Processo de eutrofização em um sistema utilizado para a criação \\ da tilápia do Nilo (Oreochromis niloticus), São Paulo, Brasil
}

Jeniffer Sati Pereira ${ }^{1}$, Cacilda Thais Janson Mercante ${ }^{2}$, Julio Vicente Lombardi ${ }^{2}$, André Martins Vaz-dos-Santos ${ }^{3}$, Clóvis Ferreira do Carmo ${ }^{2}$ and João Alexandre Saviolo Osti ${ }^{4}$

${ }^{1}$ Programa de Pós-graduação em Ciências Biológicas, Universidade Estadual Paulista "Júlio de Mesquita Filho" - UNESP, CEP 13506-900, Rio Claro, SP, Brazil e-mail: jeniffer_pereira@yahoo.com.br

${ }_{2}^{2}$ Instituto de Pesca, Av. Francisco Matarazzo, 455, Parque da Água Branca, CEP 05001-900, São Paulo, SP, Brazil

e-mail: cthais@pesca.sp.gov.br; lombardi@pesca.sp.gov.br; clovis@pesca.sp.gov.br

${ }^{3}$ Curso de Ciências Biológicas, Universidade São Judas Tadeu - USJT, Rua Taquari, 546, Mooca, CEP 03166-000, São Paulo, SP, Brazil e-mail: prof.andre@usjt.br

${ }^{4}$ Centro de Aquicultura, Universidade Estadual Paulista "Júlio de Mesquita Filho" - UNESP, Via de Acesso Professor Paulo Donato Castellane, s/n, CEP 14884-900, Jaboticabal, SP, Brazil e-mail: jale.osti@gmail.com

\begin{abstract}
Aquaculture is composed of various themes of interest, particularly does eutrophization due to feeding have direct effects on fish ponds and the whole aquatic system. This study focused on the study of the water quality of an aquatic system related to Nile tilapia (Oreochromis niloticus) rearing. Sampling was done at six sites during one rearing cycle (six months), taking water from the source of water supply, the fish pond itself, the effluent of the fish pond and the mixed waters. A principal component analysis revealed that, among all the environmental variables analyzed, chlorophyll- $a$, total nitrogen and phosphorus and organic matter were responsible for the variations observed during the rearing cycle. Other sources of variability extrinsic to the fish pond make it evident that the assessment must take the entire aquatic system related to the rearing into consideration, minimizing negative effects.
\end{abstract}

Keywords: pisciculture, Oreochromis niloticus, nitrogen, phosphorus, environment.

Resumo: Dos vários aspectos inerentes à aquicultura, a eutrofização devido ao manejo alimentar tem efeitos diretos no viveiro e no sistema aquático no qual ele está inserido. Neste contexto, o presente estudo objetivou analisar a qualidade da água do sistema aquático de um viveiro. Em uma criação de tilápia do Nilo (Oreochromis niloticus), foram realizadas coletas de água em seis pontos do sistema aquático, durante um ciclo de engorda (seis meses), compreendendo a água de abastecimento, o viveiro, o efluente e sua mistura com as águas do sistema. Das variáveis ambientais analisadas nas amostras, a aplicação de uma análise de componentes principais revelou que as concentraçóes de clorofila- $a$, nitrogênio e fósforo total e o teor de matéria orgânica foram responsáveis pelas variaçóes observadas no sistema durante o cultivo. Variaçóes extrínsecas ao viveiro de cultivo deixaram evidente que o manejo deve ser aplicado a todo o sistema aquático, minimizando efeitos ambientais negativos.

Palavras-chave: piscicultura, Oreochromis niloticus, nitrogênio, fósforo, meio ambiente.

\section{Introduction}

Aquaculture, the culture of aquatic organisms, is the most rapidly growing segment of animal production in the world, having exceeded the growth rates of cattle, poultry and swine cultures (Ono and Kubitza 2003; Kutty, 2005; Cao et al.,
2007). This growth is the consequence of the increase in world population and of the limits of extractive fisheries for human consumption (FAO, 2012). The practice of fish farming (pisciculture) has grown considerably in all the regions of the 
world, mainly due to the great potential of the activity, which presents low costs and constitutes an important source of animal protein (Arana, 2004; FAO, 2012). In Brazil, the most recent data of the fisheries statistics show an increase of 16,9\% in 2010 over 2009 in inland aquaculture, the production of which exceeded $394.340 \mathrm{t}$ (Brasil, 2010).

As a farming activity, aquaculture not only requires adequate technology for its development, but also calls for environmental conditions favorable to the production of organisms of commercial interest (Talbot and Hole, 1997; Kubtiza, 1998). Beyond the concern with the quality of the water in the culture hatchery, attention must be paid to the impact which the undertaking may have on its surroundings, due to the quality of the effluent generated by the activity (Baccarin and Camargo, 2005), which may have negative environmental consequences (Zhang et al., 2004; Macedo and Sipaúba-Tavares, 2005; Zhang and Fang, 2006; Sará, 2007; Simóes et al., 2008).

The greatest damage done to the water used in pisciculture (and in aquaculture as a whole) is due to its enrichment (eutrophization) caused by feed management. This is because the quantity of feed supplied should be proportional to the consumption of the organisms concerned, because overfeeding in addition to the high excretion rate of the fish leads to an increase in the concentrations of phosphate and nitrogenized compounds, thus affecting the cultivated organisms directly and causing great proliferation of algae and changing the dynamics of the gases and nutrients in the environment (Piedrahita, 2003; Stephens and Farris, 2004; Zhang and Fang, 2006; Rahman et al., 2008a). The eutrophization of the water is a particularly evident problem in the developing countries, where there are generally no specific regulations (or where they are not fully complied with) and, further, where the producers are not greatly worried about any possible impact caused by their aquaculture (Baccarin and Camargo, 2005). Cao et al. (2007) commented on the need for clean water for the development of the aquaculture which is, paradoxically, a polluting activity.

Within this context, sustainable aquaculture may be defined as the profitable production of aquatic organisms which maintains a permanent harmonious interaction with the local ecosystems and communities and should be assessed in environmental, economic and social terms (Valenti, 2008a, b; Boyd et al., 2007).

From the environmental point of view, various studies, among them being those of Zhang et al.
(2004), Sorokin et al. (2006) and Zhang and Fang (2006), have emphasized the importance of assessing the degradation of the water which is used in these activities.

There are few studies, especially in Brazil, focusing on the possible impact that aquaculture may have on aquatic bodies. Thus it is that the work of Baccarin and Camargo (2005) is noteworthy in that it assesses the effect of different types of food on the quality of the effluent produced by a nile tilapia (Oreochormis niloticus) farm; as also that of Mercante et al. (2004, 2005, 2006) who characterized the process of eutrophization in the fish pond and the effluent and discuss the high levels of nitrogen and phosphorus measured at these sites; and that of Simôes et al. (2008) developed recently an index to evaluate aquatic environments and that of Bazante-Yamaguishi et al. (2009), who, by means of ecotoxicological assays in tilapia cultivation observed acute and chronic toxicities through tests carried out with Ceriodaphnia dubia, and this was indicated as a result of the great quantities of phosphorus in the fish pond and effluent.

In terms of legislation, the CONAMA Resolution 357/2005 (Brasil, 2005) recognizes that the need for the treatment of effluents and, thus, for studies which should assess the degree of pollution of the receiving water are of the greatest importance, to minimize the impact caused by this activity by means of proposals for its management. As is set out in its $4^{\text {th }}$ Chapter, article 24,

[...] the effluents from any polluting source may only be delivered, whether directly or indirectly, into any natural source, after the appropriate treatment and so long as they comply with the conditions, standards and demands set out in this Resolution and other relevant normative decrees $[\ldots]$.

In this context, the knowledge of the conditions of the water (particularly its conditions in terms of nitrogen and phosphorus) and of the factors that interfere with the metabolism of these same systems is fundamental to the minimization of the impact generated by the elimination of the effluents (Mercante et al., 2007).

This present study aimed to evaluate the water quality emphasizing the eutrophication process in a fish pond within a system of cultivation as a whole including the source of water supply; the fish pond itself and its effluent; the mixing of the effluent water and the receiving water and its upstream and downstream water, viewing its management.

\section{Material and Methods}

This study was carried out in a system for the cultivation of nile tilapia (Oreochromis niloticus) for 
research purposes, located in Pindamonhangaba county (22 $56^{\prime} 27^{\prime \prime} \mathrm{S}$ and $\left.45^{\circ} 26^{\prime} 32,2^{\prime \prime} \mathrm{W}\right)$ in the State of São Paulo, Brazil.

The fish pond has a surface area of $1500 \mathrm{~m}^{2}$, volume of $1620 \mathrm{~m}^{3}$ and water residence time of 7 days. A previous survey of the site revealed that the fish pond had been prepared by local laborers, just before the present experiment was begun. This preparation included specific management measures, as follows: the pond was drained and dried in the sun, and later limed with $150 \mathrm{~kg}$ of pure lime throughout the extension of the system, for its decontamination. After this liming the site was drained several times for the removal of the lime and then filled with water and the initial fertilizing $(150 \mathrm{~kg})$ was undertaken with superphosphate $\left(6 \mathrm{~g} \cdot \mathrm{m}^{-2}\right)$ and phosphate of ammonia $\left(4 \mathrm{~g} \cdot \mathrm{m}^{-2}\right)$. Soundings were then carried out to discover the depth, area and volume of the water.

The hatchery was stocked with 3750 juveniles of nile tilapia (Oreochromis niloticus) with an average weight of $191 \mathrm{~g}$, at a density of 2.5 fish per square meter. During their cultivation, fish were fed twice a day with extruded feed containing $28 \%$ of crude protein. The feed was supplied according to the proportional quantities based on the stage of development of the population (size/age), in rate that ranged from 2.5 to $1.5 \%$ of the total biomass estimated.

Cultivation was finalized in a period of 127 days, the individuals showed a survival rate of $93 \%$ and reaching final average weight of $662.85 \mathrm{~g}$. The apparent feed conversion ratio was (1.2: 1) (2.21: 1).

Checks and monthly collections of water samples were made during the period from November, 2006 to April, 2007 (months 1 to 6) for the analyses of the environmental variables.

Water samples were collected with a Van Dorn sampler at the sub-surface of the pond and at the receiving water. Six sites were sampled (Figure 1): upstream from the fish pond (source of water supply) (SI); in the fish pond itself (SII); in the effluent of the fish pond (water drainage system) (SIII); upstream from the point of the mixing of the waters (at a distance of approximately $11 \mathrm{~m}$ ) (SIV); at the site of the mixing of the waters (the place where the effluent is delivered into the receiving water) (SV), and downstream from the mixing of the waters (SVI). Data of the flow $\left(\mathrm{L} . \mathrm{s}^{-1}\right)$ were obtained at sites I, III (volumetric methodology) e $\mathrm{V}$ ( based on a time and a known distance that a float crosses).

The variables: $\mathrm{pH}$, electrical conductivity $\left(\mu \mathrm{S} . \mathrm{cm}^{-1}\right)$, turbidity (NTU), temperature $\left({ }^{\circ} \mathrm{C}\right)$ and dissolved oxygen (DO) (mg. $\mathrm{L}^{-1}$ and saturation, as a percentage) were measured, both at the selected sites and below the surface, with the use of a water quality meter Horiba U-22 multiparameter. Collections of water were also made below the surface, to obtain the data in the laboratory. Water samples were collected with a Van Dorn bottle and then transferred to polyethylene flasks of $1 \mathrm{~L}$ capacity, wrapped in aluminum foil and kept in an isothermic case, with the temperature around $4^{\circ} \mathrm{C}$, until their arrival at the laboratory.

The analysis of the organic material (OM) content, of the total solids in suspension (TSS), of the alkalinity and hardness was made in the laboratory, in accordance with the methods described in (APHA, 2005). The estimate of the concentration of ammonia (mg. $\left.\mathrm{L}^{-1}\right)$ was made in accordance with Nessler's technique (APHA, op. cit.); for the nitrite and nitrate concentrations ( $\mu$ g. $\left.\mathrm{L}^{-1}\right)$ Griess's modified technique was employed (Giné et al., 1980); estimates of the total phosphorus and total nitrogen concentrations $\left(\mu \mathrm{g} . \mathrm{L}^{-1}\right)$ were obtained in accordance with the techniques described by (Valderrana, 1981). The alkalinity values were used as the basis for the measurement of the values for free carbonic gas, by the application of Cole's methodology (1979). The concentration of orthophosphate $\left(\mu \mathrm{g} . \mathrm{L}^{-1}\right)$ was measured by the

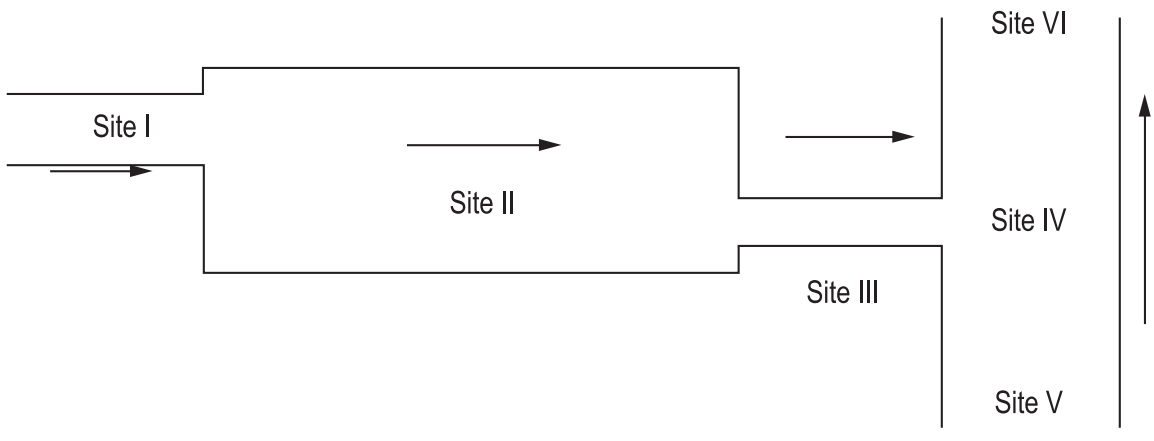

Figure 1. Sampling sites along the flow system. 
application of Strickland and Parsons' technique (1960).

Phytoplanktonic biomass was estimated by the concentration of chlorophyll- $a$ ( $\left.\mu \mathrm{g} . \mathrm{L}^{-1}\right)$, the samples being filtered by vacuum pump. Millipore filters of $45 \mu \mathrm{m}$ pore-size were used for the filtration. The technique for the extraction of the pigments was employed with the use of ethanol $90 \%$ as an organic solvent, (Marker et al., 1980; Sartory and Grobellar, 1984).

The environmental data (flow, $\mathrm{pH}$, conductivity, turbidity, DO, O2 saturation, temperature, OM, TSS, alkalinity, hardness, concentrations of ammonia, nitrite, nitrate, total nitrogen, orthophosphate, total phosphorus and chlorophyll-a) were submitted to a descriptive joint analysis. An analysis of the principal components (PCA) (flow was not included) with the data transformed [LOG $(x+1)$ ] was undertaken to ascertain the relations among and the importance of the environmental variables, on the basis of the correlation matrix (Manly, 2008). The Multi-variate Statistical Package 3.11 (MVSP) program, authorized for use by the University of São Paulo, was employed.

Taking into consideration only those variables of the greatest explicative importance on the first two axes of the PCA, their averages per period (the six months) and by site (the sampling sites), were calculated separately. After normality (D'Agostino Pearson) and homocedasticity (Levene) tests, transformation of the data and analysis of the residuals of the analysis of variance, the data were submitted to the Kruskal-Wallis test, followed by the Student Newman Keuls test to detect differences between (i) the periods and (ii) the sampling sites (Zar, 1999). In these tests a $=0.05$ was adopted, the BioEstat 5.0 program (free) being used.

\section{Results and Discussion}

The statistical description of the environmental variables measured appears in Table 1 . Wide variations, revealed by the values of the coefficients of variation $(\mathrm{V})$, were observed regarding flow, turbidity, concentration of organic matter $(\mathrm{OM})$, total solids

Table 1. Statistical description of environmental variables (details in the text) measured by the collection of water during the cultivation of Oreochromis niloticus.

\begin{tabular}{|c|c|c|c|c|c|c|c|}
\hline Variable & $\begin{array}{l}\text { Flow } \\
\left(\text { L.s }^{-1}\right)\end{array}$ & $\mathrm{pH}$ & $\begin{array}{c}\text { COND } \\
\left(\mu \mathrm{S} . \mathrm{cm}^{-1}\right)\end{array}$ & $\begin{array}{l}\text { TURB } \\
\text { (NTU) }\end{array}$ & $\begin{array}{c}\text { DO } \\
\left(\mathrm{mg} \cdot \mathrm{L}^{-1}\right)\end{array}$ & $\begin{array}{c}\text { DO } \\
\text { (\% Sat) }\end{array}$ & $\begin{array}{l}\text { Temp } \\
\left({ }^{\circ} \mathrm{C}\right)\end{array}$ \\
\hline$n$ & 18 & 36 & 36 & 24 & 36 & 36 & 36 \\
\hline Minimum & 0.86 & 5.04 & 55.00 & 5.80 & 4.26 & 72.33 & 20.68 \\
\hline Median & 3.21 & 6.15 & 71.50 & 26.55 & 6.88 & 114.80 & 26.35 \\
\hline Maximum & 2040.00 & 6.84 & 100.00 & 178.00 & 8.64 & 145.65 & 31.30 \\
\hline Mean & 157.13 & 6.15 & 71.58 & 38.64 & 6.64 & 111.50 & 26.32 \\
\hline SD & 477.69 & 0.54 & 11.51 & 47.08 & 1.08 & 17.28 & 2.74 \\
\hline V & $304.01 \%$ & $8.74 \%$ & $16.08 \%$ & $121.83 \%$ & $16.21 \%$ & $15.50 \%$ & $10.41 \%$ \\
\hline \multicolumn{8}{|c|}{ Normality Test } \\
\hline $\mathrm{K} 2$ & 62.52 & 3.15 & 2.59 & 27.50 & 2.76 & 4.77 & 0.85 \\
\hline$P$ & $<0.0001^{*}$ & 0.2074 & 0.2744 & $<0.0001^{*}$ & 0.251 & $0.0922^{*}$ & 0.6542 \\
\hline Variable & $\begin{array}{l}\text { TDS } \\
\left(\mathbf{g} \cdot \mathrm{L}^{-1}\right)\end{array}$ & $\begin{array}{l}\text { ORP } \\
(\mathrm{mV})\end{array}$ & $\begin{array}{c}\text { OM } \\
\left(\mathrm{mg} \cdot \mathrm{L}^{-1}\right)\end{array}$ & $\begin{array}{l}\text { TSS } \\
\text { (mg) }\end{array}$ & $\begin{array}{c}\text { DBO } \\
\left(\mathrm{mg}^{-L^{-1}}\right)\end{array}$ & $\begin{array}{c}\text { Alkalinity } \\
\left(\mathrm{mg} \text { of } \mathrm{CaCO}_{3} \text { ) }\right.\end{array}$ & $\begin{array}{l}\text { Hardness } \\
\left(\mathrm{mg} \cdot \mathrm{L}^{-1}\right)\end{array}$ \\
\hline $\mathrm{n}$ & 36 & 36 & 36 & 36 & 30 & 36 & 36 \\
\hline Minimum & 0.04 & 138.00 & 0.33 & -11.67 & -1.40 & 18.46 & 13.86 \\
\hline Median & 0.05 & 203.50 & 6.70 & 20.33 & 0.29 & 22.67 & 17.82 \\
\hline Maximum & 0.48 & 298.00 & 152.50 & 167.20 & 1.40 & 36.61 & 25.74 \\
\hline Mean & 0.06 & 202.92 & 24.38 & 30.06 & 0.36 & 23.98 & 18.40 \\
\hline SD & 0.07 & 47.49 & 36.20 & 38.92 & 0.56 & 3.97 & 2.03 \\
\hline V & $126.83 \%$ & $23.40 \%$ & $148.47 \%$ & $129.45 \%$ & $153.90 \%$ & $16.56 \%$ & $11.02 \%$ \\
\hline \multicolumn{8}{|c|}{ Normality Test } \\
\hline $\mathrm{K} 2$ & 102.20 & 4.33 & 32.52 & 48.82 & 10.10 & 13.29 & 14.41 \\
\hline$P$ & $<0.0001^{*}$ & 0.1145 & $<0.0001^{*}$ & $<0.0001^{*}$ & $0.0064^{*}$ & $0.0013^{*}$ & $<0.0001^{*}$ \\
\hline Variable & $\begin{array}{c}\text { Ammonia } \\
\left(\mathrm{mg} \cdot \mathrm{L}^{-1}\right)\end{array}$ & $\begin{array}{l}\text { Nitrite } \\
\left(\mu g \cdot L^{-1}\right)\end{array}$ & $\begin{array}{l}\text { Nitrate } \\
\left(\mu g . L^{-1}\right)\end{array}$ & $\begin{array}{c}\text { Total } \\
\text { Nitrogen } \\
\left(\mu \mathrm{g} \cdot \mathrm{L}^{-1}\right)\end{array}$ & $\begin{array}{l}\text { Orthophosphate } \\
\qquad\left(\mu \mathrm{g} \cdot \mathrm{L}^{-1}\right)\end{array}$ & $\begin{array}{c}\text { Total } \\
\text { Phosphorus } \\
\left(\mu \mathrm{g} \cdot \mathrm{L}^{-1}\right)\end{array}$ & $\begin{array}{c}\text { Clorophyll a } \\
\left(\mu \mathrm{g} \cdot \mathrm{L}^{-1}\right)\end{array}$ \\
\hline $\mathrm{n}$ & 36 & 36 & 36 & 36 & 36 & 36 & 36 \\
\hline Minimum & 0.39 & 2.73 & 0.01 & 37.25 & 3.56 & 21.76 & 0.00 \\
\hline Median & 0.57 & 5.28 & 0.03 & 387.77 & 12.59 & 83.53 & 5.50 \\
\hline Maximum & 1.87 & 229.15 & 0.24 & 3426.33 & 61.41 & 379.17 & 137.10 \\
\hline
\end{tabular}

$\mathrm{n}=$ number of observations, $\mathrm{SD}=$ standard deviation, $\mathrm{V}=$ coefficient of variation). Result of D'Agostino Pearson's normality test $\left(\mathrm{K} 2\right.$ = test statistic, $\mathrm{P}=$ probability index, ${ }^{*}$ significant values. 
Table 1. Continued...

\begin{tabular}{|c|c|c|c|c|c|c|c|}
\hline Variable & $\begin{array}{l}\text { Flow } \\
\left(\text { L. } \text { s }^{-1}\right)\end{array}$ & $\mathrm{pH}$ & $\begin{array}{c}\text { COND } \\
\left(\mu \mathrm{S} . \mathrm{cm}^{-1}\right)\end{array}$ & $\begin{array}{l}\text { TURB } \\
\text { (NTU) }\end{array}$ & $\begin{array}{c}\mathrm{DO} \\
\left(\mathrm{mg} \cdot \mathrm{L}^{-1}\right)\end{array}$ & $\begin{array}{c}\text { DO } \\
\text { (\% Sat) }\end{array}$ & $\begin{array}{l}\text { Temp } \\
\left({ }^{\circ} \mathrm{C}\right)\end{array}$ \\
\hline Mean & 0.67 & 23.49 & 0.05 & 583.93 & 15.63 & 130.82 & 21.14 \\
\hline SD & 0.35 & 52.88 & 0.05 & 725.84 & 12.80 & 108.85 & 33.14 \\
\hline V & $52.49 \%$ & $225.16 \%$ & $102.28 \%$ & $124.30 \%$ & $81.88 \%$ & $83.21 \%$ & $156.71 \%$ \\
\hline \multicolumn{8}{|c|}{ Normality Test } \\
\hline K2 & 39.35 & 61.90 & 37.06 & 43.27 & 31.84 & 7.52 & 29.36 \\
\hline $\mathrm{P}$ & $<0.0001^{*}$ & $<0.0001^{*}$ & $<0.0001^{*}$ & $<0.0001^{*}$ & $<0.0001^{*}$ & $0.0233^{*}$ & $<0.0001^{*}$ \\
\hline
\end{tabular}

$\mathrm{n}=$ number of observations, $\mathrm{SD}=$ standard deviation, $\mathrm{V}=$ coefficient of variation). Result of D'Agostino Pearson's normality test $\left(\mathrm{K} 2\right.$ = test statistic, $\mathrm{P}=$ probability index, ${ }^{*}$ significant values.

in suspension (TSS), concentrations of ammonia, nitrite, nitrate, total nitrogen, orthophosphate, total phosphorus and chlorophyll- $a$. These results were expected in view of the system's dynamics, highly susceptible to its assessment.

The average flow obtained from the receiving water of the system was of $2.76 \mathrm{~L} . \mathrm{s}^{-1}$ and the average time for the passage of the water was 7 days, thus qualifying the system in the transitional category of the lotic and lentic ecosystem (Brasil, 2005).

As regards the nitrogenized inorganic forms, despite the variation shown, no increase was observed in their concentrations even after fertilization and feeding. The nitrate concentrations remained constantly below $0.22 \mu \mathrm{g} . \mathrm{L}^{-1}$ and those of nitrite below $225 \mu \mathrm{g} . \mathrm{L}^{-1}$ in practically every case. Due to the low values of $\mathrm{pH}$ (acidity), there was no formation of toxic ammonia and the concentration of total ammonia remained below $1.87 \mathrm{mg} . \mathrm{L}^{-1}$ throughout the experiment.

In the analysis of the principal components (Figure 2), the first axis accounted for $42.307 \%$ of the joint variation of the data and the second for $23.413 \%$ (Table 2). The distribution of the samples on the bivariate graph (Figure 2) is to be explained, as regards the first component, by the high concentrations of chlorophyll- $a(0.703)$, total nitrogen (0.488) and total phosphorus (0.402), respectively. The second component is to be explained essentially by the level of organic matter (0.831), the other variables having little influence on the axis. It may be seen from the bivariate graph that the fish pond (SII) and the effluent (SIII) were characterized by the combination of the high concentrations of chlorophyll- $a$, nitrogen and total phosphorus, especially in December and January, tending to diminish later, and to the low concentrations of organic material.

As regards the concentration of chlorophyll- $a$, the values varied from $7.87 \mu \mathrm{g} . \mathrm{L}^{-1}$ to $37.10 \mu \mathrm{g} . \mathrm{L}^{-1}$ as among periods (Table 3 ), a variation which was without significance during the rearing cycle (Table 4). On the other hand, the average
Table 2. Eigenvalues, percentages and vector values of Principal Component Analysis.

\begin{tabular}{|c|c|c|}
\hline PCA & Axis 1 & Axis 2 \\
\hline Eigenvalues & 0.663 & 0.367 \\
\hline Percentage & 42.307 & 23.413 \\
\hline \multicolumn{3}{|l|}{ PCA variable loadings } \\
\hline $\mathrm{pH}$ & 0.000 & -0.011 \\
\hline COND $\left(\mu \mathrm{S} . \mathrm{cm}^{-1}\right)$ & 0.003 & -0.007 \\
\hline $\mathrm{DO}\left(\mathrm{mg} \cdot \mathrm{L}^{-1}\right)$ & -0.032 & -0.001 \\
\hline DO (\% sat) & -0.022 & -0.001 \\
\hline Temp $\left({ }^{\circ} \mathrm{C}\right)$ & 0.029 & -0.001 \\
\hline TDS $\left(g \cdot L^{-1}\right)$ & 0.001 & 0.005 \\
\hline ORP (mV) & 0.012 & -0.060 \\
\hline $\mathrm{MO}\left(\mathrm{mg} \cdot \mathrm{L}^{-1}\right)$ & 0.162 & 0.831 \\
\hline TSS (mg) & 0.193 & 0.332 \\
\hline Alkalinity $\left(\mathrm{mg}\right.$ of $\left.\mathrm{CaCO}_{3}\right)$ & 0.009 & 0.008 \\
\hline Hardness $\left(m g \cdot L^{-1}\right)$ & 0.011 & 0.000 \\
\hline Ammonia (mg. $\mathrm{L}^{-1}$ ) & 0.027 & -0.038 \\
\hline Nitrite $\left(\mu \mathrm{g} \cdot \mathrm{L}^{-1}\right)$ & 0.113 & -0.339 \\
\hline Nitrate $\left(\mu \mathrm{g} \cdot \mathrm{L}^{-1}\right)$ & -0.006 & 0.000 \\
\hline Nitrogen $\left(\mu \mathrm{g} \cdot \mathrm{L}^{-1}\right)$ & 0.488 & -0.273 \\
\hline Orthophosphate $\left(\mu \mathrm{g} \cdot \mathrm{L}^{-1}\right)$ & 0.159 & -0.071 \\
\hline Total Phosphorus $\left(\mu \mathrm{g} \cdot \mathrm{L}^{-1}\right)$ & 0.402 & -0.001 \\
\hline Clorophyll a $\left(\mu \mathrm{g} . \mathrm{L}^{-1}\right)$ & 0.703 & -0.020 \\
\hline
\end{tabular}

concentrations of chlorophyll- $a$ were significantly high at sites II and III of the system (Tables 5 and 6), demonstrating intense photosynthetic activity. At the end of the cultivation these values attained $92.0 \mu \mathrm{g} . \mathrm{L}^{-1}$, indicating an intense eutrophication process, although the acceptable limits established by the CONAMA (2005) Resolution 357/2005 include chlorophyll- $a$ below $30 \mu \mathrm{g} . \mathrm{L}^{-1}$. Rahman et al. (2008a, b, c) recently ascertained that, in cultivations including those of tilapia, the concentration of chlorophyll- $a$ varies in accordance with the availability of food and the strategy adopted by the species (alternation between omnivorous - feed and herbivorous - phytoplankton).

The concentration of total nitrogen was significantly low at the beginning of the experiment $\left(65.19 \mu \mathrm{g} . \mathrm{L}^{-1}\right)$, in November, 2006, attaining its maximum value in February, 20 times greater $\left(1272,35 \mu \mathrm{g} . \mathrm{L}^{-1}\right)$ than the initial one (Tables 3 and 4$)$. As regards the variation among the sites, it 


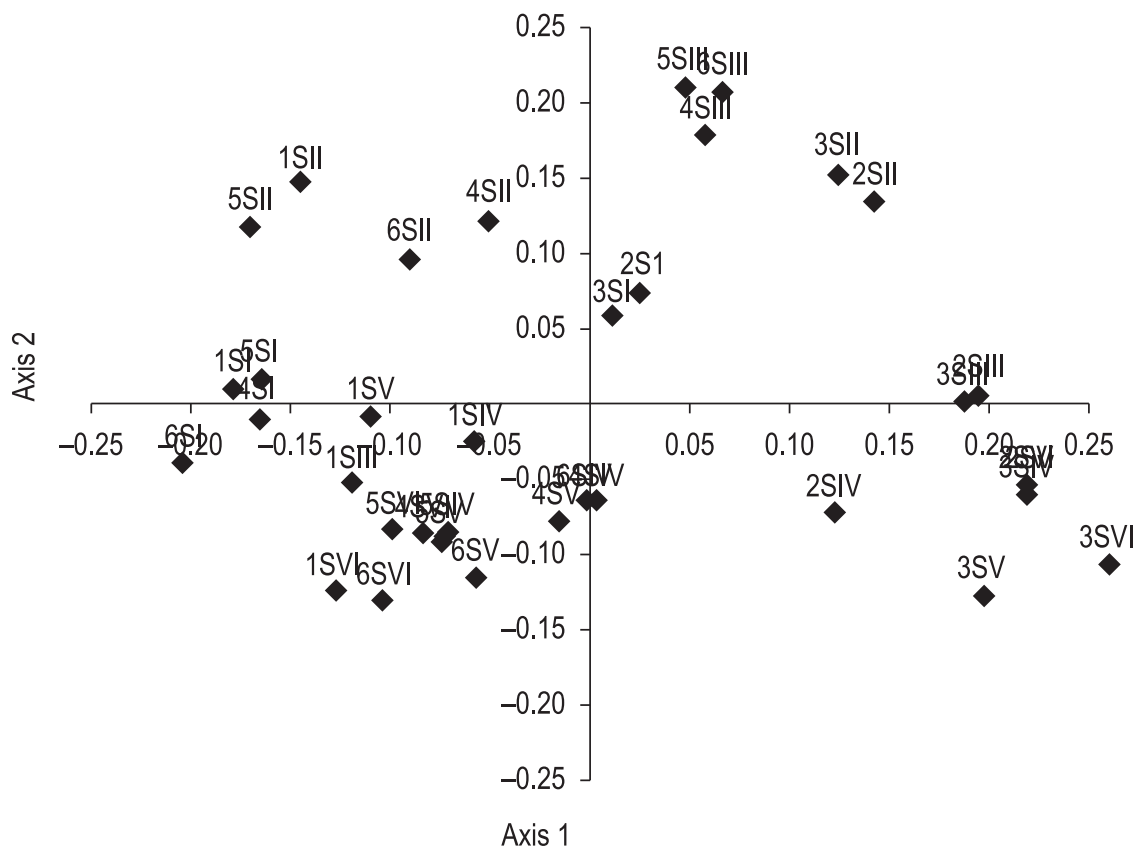

Figure 2. Bivariate graph showing the distribution of samples (the label indicating the period and the site of collection) in the analysis of principal components (PCA).

Table 3. Average values of the environmental variables with explicative importance in the collection of water in the rearing system of Oreochromis niloticus, by period of collection.

\begin{tabular}{lrrrrrr}
\hline \multicolumn{1}{c}{ Variable } & \multicolumn{7}{c}{ Period of Collection } \\
\cline { 2 - 7 } & Nov (1) & Dec (2) & Jan (3) & Feb (4) & Mar (5) & Apr (6) \\
\hline Chlorophyll-a $\left(\mu \mathrm{g} \cdot \mathrm{L}^{-1}\right)$ & 7.87 & 11.37 & 27.75 & 17.15 & 25.63 & 37.10 \\
Total nitrogen $\left(\mu \mathrm{g} \cdot \mathrm{L}^{-1}\right)$ & 65.19 & 229.15 & 792.52 & 1272.35 & 666.50 & 477.84 \\
Total phosphorus $\left(\mu \mathrm{g} \cdot \mathrm{L}^{-1}\right)$ & 68.39 & 123.03 & 132.20 & 157.22 & 142.58 & 161.49 \\
OM $\left(\mathrm{mg} \cdot \mathrm{L}^{-1}\right)$ & 9.17 & 56.67 & 64.28 & 5.41 & 3.78 & 7.00 \\
\hline
\end{tabular}

Table 4. Results of the application of the Kruskal Wallis and SNK tests for the comparison of the series of data collated from the collection of water from the system of cultivation, by period of collection.

\begin{tabular}{lrlc}
\hline \multicolumn{1}{c}{ Variable } & H & P & Differences among periods of collection (SNK) \\
\hline Chlorophyll-a $\left(\mu \mathrm{g} \cdot \mathrm{L}^{-1}\right)$ & 4.56 & 0.471 & - \\
Total Nitrogen $\left(\mu \mathrm{g} \cdot \mathrm{L}^{-1}\right)$ & 16.66 & $0.005^{*}$ & $(1$ and $3,4,5,6),(2$ and 4$)$ \\
Total phosphorus $\left(\mu \mathrm{gg} \cdot \mathrm{L}^{-1}\right)$ & 2.14 & 0.892 & - \\
OM $\left(\mathrm{mg} \cdot \mathrm{L}^{-1}\right)$ & 19.36 & $0.002^{*}$ & $(1$ and 2$),(2$ and $4,5,6),(3$ and $4,5,6)$ \\
\hline
\end{tabular}

$\mathrm{H}=$ Kruskal Wallis statistical test, $\mathrm{P}=$ probability value, ${ }^{*}$ significant values.

Table 5. Average values of environmental variables of explicative importance in the collection of water from the cultivation system, by site of collection.

\begin{tabular}{lcccccc}
\hline \multirow{2}{*}{ Variable } & \multicolumn{9}{c}{ Site } \\
\cline { 2 - 7 } & SI & SII & SIII & SIV & SV & SVI \\
\hline Chlorophyll-a $\left(\mu \mathrm{g} \cdot \mathrm{L}^{-1}\right)$ & 2.87 & 52.62 & 61.23 & 4.25 & 2.87 & 3.03 \\
Total nitrogen $\left(\mu \mathrm{g} \cdot \mathrm{L}^{-1}\right)$ & 196.65 & 1098.49 & 1279.81 & 325.44 & 263.28 & 339.88 \\
Total phosphorus $\left(\mu \mathrm{g} \cdot \mathrm{L}^{-1}\right)$ & 42.20 & 252.40 & 245.48 & 126.39 & 53.67 & 64.78 \\
OM $\left(\mathrm{mg} \cdot \mathrm{L}^{-1}\right)$ & 12.23 & 23.07 & 20.39 & 27.36 & 29.22 & 34.03 \\
\hline
\end{tabular}

was discovered that, after the entrance of the water (SI), total nitrogen underwent a great increase in its concentrations, attaining average values of the order of magnitude of up to $13 \times$ that of the inflow system (water supply). The greatest average values of the concentration of total nitrogen were observed in the fish pond (SII), at $1098.49 \mu \mathrm{g} . \mathrm{L}^{-1}$, and in the effluent (SIII), at $1279.81 \mu \mathrm{g} . \mathrm{L}^{-1}$ (Tables 5 and 6). 
Table 6. Results of the application of the Kruskal Wallis and SNK tests for the comparison of the series of data collated from the collection of water from the system of cultivation, by collection site.

\begin{tabular}{lccc}
\hline \multicolumn{1}{c}{ Variable } & H & P & Differences among sampling sites (SNK) \\
\hline Chlorophyll-a $\left(\mu \mathrm{g} \cdot \mathrm{L}^{-1}\right)$ & 23.42 & $<0.001^{*}$ & (I and II, III), (II and IV, V, VI), (III and IV, V, VI) \\
Total nitrogen $\left(\mu \mathrm{g} \cdot \mathrm{L}^{-1}\right)$ & 14.24 & $0.014^{*}$ & $(\mathrm{I}$ and II, III), (II and V), (III and V) \\
Total phosphorus $\left(\mu \mathrm{g} \cdot \mathrm{L}^{-1}\right)$ & 24.46 & $<0.001^{*}$ & (I and II, III, IV), (II and V, VI), (III and V, VI) (IV and V) \\
OM (mg. $\left.\mathrm{L}^{-1}\right)$ & 4.10 & 0.535 & - \\
\hline
\end{tabular}

$\mathrm{H}=$ Kruskal Wallis statistical test, $\mathrm{P}=$ probability value, ${ }^{*}$ significant values.

As concerns the average concentration of total phosphorus, despite not having differed significantly between the periods of the experiment (Tables 3 and 4), it behaved exactly as the total nitrogen, being significantly higher also in the fish pond, at $252.40 \mu \mathrm{g} . \mathrm{L}^{-1}$, and in the effluent, at $245.48 \mu \mathrm{g} . \mathrm{L}^{-1}$.

As was expected, the highest values of nitrogen and total phosphorus arose from the supply of feed. This result has also been observed by various other authors, among them being Kochba et al. (1994), D'Silva and Maughan (1995), Boyd and Tucker (1998), Avnimelech et al. (1999), Mercante et al. (2004, 2007) and Rahman et al. (2008c). Apart from the feed, the enrichment with nitrogen and phosphorus in pisciculture ponds may also occur due to the entry of other compounds, such as manure and fertilizers, which contain this element (Boyd and Tucker, 1998; McIntosh, 2000; Macedo and Sipaúba-Tavares, 2005; Mercante et al., 2007).

From the variables directly related to the process of eutrophication, chlorophyll- $a$ and total phosphorus did not vary significantly over the period of cultivation, presenting no temporal variation (Tables 3 and 4). This fact has already been observed by Mercante et al. (2004), who deduced that management exercises a greater influence on the dynamics of the systems of cultivation than does temporal variation. In this present study, the same may be attributed to the results obtained by the authors mentioned above, because the feeding management had greater influence in the incorporation of the total phosphorus. Clearly, the water throughout the period of cultivation presented excessive quantities of this element, though this did not limit the phytoplankton community.

As for the feeding management and its influence on the systems of cultivation, the various abovementioned authors are unanimous in considering the commercial food provided as being the principal form of pollution.

Baccarin and Camargo (2005) especially, who assessed different types of feeding management and their relation to the quality of the water in the effluent of a tilapia farm, observed a positive correlation between the growth and the biomass of the fish and the increase in the concentration of nitrogen and total phosphorus in the water. This happens because the fish (in this case, O. niloticus) retain only a part $(-30 \%)$ of these two elements obtained from their feed, which demands good feeding management (verification of the quality of the feed), treatment of the effluent, and the choice of appropriate species (Cao et al., 2007). The quality of the feed may be checked by its protein content: only $30 \%$ of the commercial food used in cultivation systems are composted of protein, which contains $16 \%$ of nitrogen, which means a rate of increase of the biomass of from 2 to $4 \%$ (Simóes et al., 2008). Thus, the quality and quantity of the feed should be weighed up carefully for the sustainability of the system of cultivation (Boyd et al., 2007). Further, Simóes et al. (op. cit.) emphasize that this importance makes it possible to establish a functional relationship between the quality of the commercial food provided and the eutrophication process.

The organic matter content (Table 3) presented significantly high average values in the months of December, 2006 (56.57 mg. $\left.\mathrm{L}^{-1}\right)$ and January, 2007 (64.28 mg. $\mathrm{L}^{-1}$ ) (Table 4), months of heavy rainfall $(104.6 \mathrm{~mm}$ and $146.1 \mathrm{~mm}$, according to local measurements), which transports particulate material from the surrounding land into the system of cultivation. In the analysis by sampling site, there was a continual increase in the level of organic matter from sites I to VI (Table 5). This result, with no plausible explanation, runs counter to what was to be expected, that is to say, greater amounts of organic matter in the fish pond (SII) and in the effluent (SIII).

On the other hand, the organic matter at sites I, IV and V indicates the influence of particulate alloctone material transported into the aquatic system. Mortatti and Probst (2003) point out that superficial particulate and dissolved material transport by aquatic bodies arise from physical and chemical processes that occur near these 
systems, such as mechanic erosion, intemperism and atmospheric events.

Many authors have discussed the transport of organic and inorganic matter in watersheds (Martinelli, 1989; Mortatti et al., 1992, 1997; Boeglin et al., 1997), commenting that continental aquatic systems are also influenced by anthropic actions that increase the concentration of total solids in suspension. As von Sperling (1996) informs us, in systems that receive domestic effluent the organic matter concentration often reaches $320 \mathrm{mg} \cdot \mathrm{L}^{-1}$. Falco (2005) adjusted a model in stabilization lagoons for the variables chlorophyll- $a$, organic nitrogen and chemical oxygen demand (COD), that presented a direct relationship to phytoplankton density, and considered that algae contribute greatly to the organic matter in these systems. In our study there was no clear relationship between organic matter and chlorophyll-a, showing that organic matter at almost none of the sites has been related to the chlorophyll- $a$ at site II, which is probably due to surface run-off.

In brief, for the sustainability environmental of systems of cultivation of $O$. niloticus, it is recommended that: (i) the maximum load of fish per unit area be restricted; (ii) commercial food of good quality and high digestibility, with low nitrogen and phosphorus concentrations and no reduction in their nutritional value, be provided; (iii) that the resulting effluent comply with the norms established by the legislation in force (Brasil, 2005). The adoption of these measures will undoubtedly reduce the impact of the system of cultivation, leading to the reduction of the levels of nitrogen, phosphorus and chlorophyll- $a$ in the environment and, consequently, acting in the control of eutrophication.

\section{Acknowledgements}

To FAPESP for financing project 2005/05180-0.

To Agencia Paulista de Tecnologia dos Agronegócios - APTA, Vale do Paraíba Regional Office, represented by Dra Cleide Shimidt Romeiro Mainardes Pinto.

To Luiz Claudio dos Santos Evangelista, for the support in the laboratory and field research.

\section{References}

American Public Health Association - APHA. 2005. Standard methods for the examination of water and wastewater. 21th ed. Washington: APHA. 1085 p.

ARANA, LV. 2004. Fundamentos de aqüicultura. Florianópolis: Ed.UFSC. 349 p.
AVNIMELECH, Y., KOCHVA, M. and HARGREAVES, JA. 1999. Sedimentation and resuspension in earthen fish ponds. Journal of the World Aquaculture Society, vol. 30, p. 401-409. http://dx.doi. org/10.1111/j.1749-7345.1999.tb00988.x

BACCARIN, AE. and CAMARGO, AFM. 2005. Characterization and evaluation of the feed management on the effluens of nile tilapia (Oreochromis niloticus) culture. Brazilian Archives of Biology and Technology, vol. 48, no. 1, p. 81-90. http:// dx.doi.org/10.1590/S1516-89132005000100012

BAZANTE-YAMAGUISHI, R., LOMBARDI, J.V., MERCANTE, C.T.J., CARUSO, N.P.P., MOREIRA, LEB. and PEREIRA, JS. 2009. Análise ecotoxicológica em viveiro de produção de tilápia (Oreochromis niloticus), utilizando o cladócero Ceriodaphnia dubia como organismo teste. Journal of the Brazilian Society of Ecotoxicology, vol. 4, p. 55-64. http://dx.doi.org/10.5132/jbse.2009.01.008

BOEGLIN, JI., MORTATTI, J. and TARDY, Y. 1997. Erosion chemique et mécanique sur le basin amont du Niger (Guiné, Mali). Bilan gechimique de l' alteration en milieu tropical. Comptes Rendus de l'Academic de Science, vol. 325, p. 185-191.

BOYD, CE. and TUCKER, CS. 1998. Pond aquaculture water quality management. Boston: Kluwer. 700 p.

BOYD, CE., TUCKER, CS., McNEVIN, A., BOSTICK, K. and CLAY, J. 2007. Indicators of resource use efficiency and environmental performance in fish and crustacean aquaculture. Reviews in Fisheries Science, vol. 15, p. 327-360. http://dx.doi. org/10.1080/10641260701624177

Brasil. Conselho Nacional do Meio Ambiente - CONAMA. 2005. Resoluçáo no 357, de 17 de março de 2005. Classificação das águas doces, salobras e salinas do Território Nacional. Diário Oficial da República Federativa do Brasil, Brasília, DF, mar. 2005. Available from: <http://www. lei.adv.br/020-86.htm>. Access in: 22 feb. 2008.

Brasil. Ministério da Pesca e Aquicultura - MPA. 2010. Boletim Estatistico da Pesca e Aquicultura 2010. Available from: <http://www.mpa.gov.br>. Access in: $15 \mathrm{dez} .2012$.

CAO, L., WANG, W., YANG, Y., YANG, C., YUAN Z., XIONG, S. and DIANA, J. 2007. Environmental impact of aquaculture and countermeasures to aquaculture pollution in China. Environmental Science and Pollution Research, vol. 14, no. 7, p. 452-462. PMid:18062476. http://dx.doi. org/10.1065/espr2007.05.426

COLE, G. 1979. A textbook of limnology. St. Louis: The C.V. Mosbycompany.

D'SILVA, AM. and MAUGHAN OU. 1995. Efects of density and water quality on red tilapia (Oreochromis mossambicus X O. urolepis hornorum) in pulsedflow culture systems. Journal of Applied Aquaculture, 
vol. 5, p. 69-76. http://dx.doi.org/10.1300/ J028v05n01_08

FALCO, PB. 2005. Estrutura da comunidade microbiana (algas e bactérias) em um sistema de lagoas de estabilizaçâa em duas escalas temporais: nictemeral e sazonal. São Carlos: Universidade de São Paulo. [Tese de Doutorado].

Food and Agriculture Organization of the United Nations - FAO. 2012. The State of World Fisheries and Aquaculture 2012. Rome. 209 p.

GINÉ, H., BERGAMIN, H., ZAGATTO, EAG. and REIS, BF. 1980. Simultaneous determination of nitrate and nitrite by flow injection analisys. Anaytica Chimica Acta, vol. 114, p. 191-197. http://dx.doi. org/10.1016/S0003-2670(01)84290-2

KOCHBA, M., DIAB, S. and AVNIMELECH, Y. 1994. Modeling of nitrogen transformation in intensively aerated fish ponds. Aquaculture, vol. 120, p. 95-104. http://dx.doi.org/10.1016/0044-8486(94)90225-9

KUBTIZA, F. 1998. Qualidade da água na produção de peixes. Panorama da Aqüicultura, vol. 46, p. 35-41.

KUTTY, MN. 2005. Towards sustainable freshwater prawn aquaculture - lessons from shrimp, with special reference to Índia. Aquacuture Research, vol. 36, p. 255-263.

MACEDO, CF. and SIPAÚBA-TAVARES, LH. 2005. Variaçóes de nutrientes e estado trófico em viveiros seqüenciais de criação de peixes. Acta Scientiarium Animal Sciences, vol. 27 no. 3, p. 405-411.

MANLY, BJF. 2008. Métodos estatísticos multivariados: uma introdução. São Paulo: Artmed. 229 p.

MARKER, AFH., NUSCH, H., RAI, H. and RIEMANN, B. 1980. The measurement of photosynthetic pigments in freshwaters and standardization of methods: conclusion and recommendations. In: Proceedings of the workshop held at Plön, 1978. MaxPlanck Institut für Limnology, Abt. Tropenökologie. vol. 14, p. 91-106.

MARTINELLI, LA. 1989. Descarge de sólidos dissolvidos totais do rio Amazonas e seu principais tributários. Geochimica Brasiliensis, vol. 3, p. 141-148.

McINTOSH, RP. 2000. Changing paradigms in shrimp farming: low protein feeds and feeding strategies. The Advocate, vol. 1, p. 48-50.

MERCANTE, CTJ., CABIANCA, MA., SILVA, V., COSTA, SV. and ESTEVES, KE. 2004. Water quality in fee-fishing ponds located in the São Paulo metropolitan region, Brazil: analysis of the eutrophication process. Acta Limnologica Brasiliensis, vol. 16, no. 1, p. 95-102.

MERCANTE, CTJ., COSTA, SV., SILVA, V., CABIANCA, MA. and ESTEVES, KE. 2005. Qualidade da água em pesque-pague da região metropolitana de São Paulo (Brasil): avaliação através de fatores abióticos (período seco e chuvoso). Acta Scientiarum, vol. 27, no. 1, p. 1-7.
MERCANTE, CTJ., MARTINS, YK., CARMO, CF., OSTI, JAS., MAINARDES-PINTO, CSR. and TUCCI, A. 2007. Qualidade de água em viveiro de Tilápia do Nilo (Oreochromis niloticus): caracterização diurna de variáveis físicas, químicas e biológica, São Paulo, Brasil. Bioikos, vol. 2, no. 2, p. 79-88.

MERCANTE, CTJ., PEREIRA, JS., MARUYAMA, LS., CASTRO, PMG., MENEZES, LB., and SENDACZ, S. 2006. Cargas de nitrogênio e fósforo de efluentes de pesque e pague visando a gestão de recursos hídricos: um estudo preliminar. In: Anais do Simpósio de Recursos Hidricos Sul-Sudeste, 2006. Curitiba.

MORTATTI, J. and PROBST, JL. 2003. Silicate rock weathering and atmospheric/soil $\mathrm{CO} 2$ uptake in the Amazon Basin estimated from river water geochemistry: seasonal and spatial variations. Chemical Geology, vol. 197, p. 177-196. http:// dx.doi.org/10.1016/S0009-2541(02)00349-2

MORTATTI, J., PROBST, JL. and FERREIRA, JR. 1992. Hydrological and geochemical characteristics of the Jamari and Jiparana river basins (Rondônia, Brazil). Geojounal, vol. 26, no. 3, p. 287-296. http://dx.doi. org/10.1007/BF02629808

MORTATTI, J., PROBST, JL. and TARDY, Y. 1997. Balanço de alteração e erosão química na Bacia Amazônica. Geochimica Brasiliensis, vol. 11, p. 2-13.

ONO, EA. and KUBTIZA, F. 2003. Cultivo de peixes em tanques-rede. 2. ed. Jundiaí: Esalq-USP. 68 p.

PIEDRAHITA, RH. 2003. Reducing the potential environmental impact of tank aquaculture effluents through intensification and recirculation. Aquaculture, vol. 226, p. 35-44. http://dx.doi.org/10.1016/S00448486(03)00465-4

RAHMAN, MM., VERDEGEM, MCJ., NAGELKERKE, LAJ., WAHAB, MA. and VERRETH, JAJ. 2008c. Relationships among water quality, food resources, fish diet and fish growth in polyculture ponds: a multivariate approach. Aquaculture, vol. 275, p. 108-115. http://dx.doi. org/10.1016/j.aquaculture.2008.01.027

RAHMAN, MM., VERDEGEM, MCJ., NAGELKERKE, LAJ., WAHAB, MA., MILSTEIN, A. and VERRETH, JAJ. 2008b. Efects of common carp Cyprinus carpio (L.) and feed addition in rohu Labeo rohita (Hamilton) ponds on nutrient partitioning among fish, plankton and benthos. Aquaculture Research, vol. 39, p. 85-95.

RAHMAN, MM., VERDEGEM, M. and WAHAB, MA. 2008a. Effects of tilapia (Oreochromis niloticus L.) stocking and artificial feeding on water quality and production in rohu-common carp bi-culture ponds. Aquaculture Research, vol. 39, p. 1579-1587.

SARÁ, G. 2007. Ecological effects of aquaculture on living and non-living suspended fractions of the water 
column: A meta-analysis. Water Research, vol. 41, p. 3187-3200. PMid:17582455. http://dx.doi. org/10.1016/j.watres.2007.05.013

SARTORY, E. and GROBELLAR, M. 1984. Extraction of chlorophyll- $a$ from freshwater phytoplankton for spectrophotometric analysis. Hydrobiologia, vol. 114, p. 177-187. http://dx.doi.org/10.1007/BF00031869

SIMÓES, FS., MOREIRA, AB., BISINOTI, MC., GIMENEZ, SNN. and YABE, MJS. 2008. Water quality index as a simple indicator of aquaculture effects on aquatic bodies. Ecological indicators, vol. 8, p. 476-484. http://dx.doi.org/10.1016/j. ecolind.2007.05.002

SOROKIN, YI., SOROKIN, PY. and RAVAGNAN, G. 2006. Hypereutrophication events in the Ca'Pisani lagoons associated with intensive aquaculture. Hydrobiologia, vol. 571, p. 1-15. http://dx.doi. org/10.1007/s10750-006-0250-9

STEPHENS, W. and FARRIS, JL. 2004. A biomonitoring approach to aquaculture effluent characterization in channel catfish fingerling production. Aquaculture, vol. 241, p. 319-330. http://dx.doi.org/10.1016/j. aquaculture.2004.08.007

STRICKLAND, JDH. and PARSONS, TRA 1960. manual of sea water analysis. Bulletin of the Fisheries Research Board of Canada Ottawa, vol. 125, p. 1-185.

TALBOT, C. and HOLE, R. 1997. Fish diets and the control of eutrophication resulting from aquaculture. Journal of Applied Ichthyology, vol. 10, p. 258-270. http://dx.doi.org/10.1111/j.1439-0426.1994. tb00165.x
VALDERRANA, JC. 1981. The simultaneous analysis of nitrogen and phosphorus total in natural waters. Marine Chemistry, vol. 10, p. 109-122. http://dx.doi. org/10.1016/0304-4203(81)90027-X

VALENTI, WCA. 2008a. Aquicultura brasileira é sustentável? In Anais do IV Seminário Internacional de Aqüicultura, Maricultura e Pesca-Aquafair, 2008. Florianópolis.

VALENTI, WC. 2008b. Anais do II Seminário sobre Aqüicultura Sustentável - Apresentação. Available from: <http://www.caunesp.unesp.br/eventos/ Seminario_Aquicultura_Sustentavel_ago_2008/ aquicultura_sustentavel.php >. Access in: 16 set. 2008.

VON SPERLING, M. 1996. Comparison among the most frequently used systems for wastewater treatment in developing countries. Water Science and Technology, vol. 33, no. 3, p. 59-72. http://dx.doi. org/10.1016/0273-1223(96)00301-0

ZAR, JH. 1999. Biostatistical analysis. 4th ed. New Jersey: Prentice Hall. 663 p.

ZHANG, M., ZHOU, Y., XIE, P., XU, P., LI, J., ZHU, D. and XIA, T. 2004. Impacts of Cage-Culture of Oreochromis niloticus on Organic Matter Content, Fractionation and Sorption of Phosphorus, and Alkaline Phosphatase Activity in a Hypereutrophic Lake, People's Republic of China. Bulletin of Environmental Contamination and Toxicology, vol. 73, p. 927-932. PMid:15669739. http://dx.doi. org/10.1007/s00128-004-0515-9

ZHANG, MK. and FANG, LP. 2006. Phosphorus accumulation and eutrophication in feed-supply freshwater fishponds. Journal of Environmental Sciences, vol. 18, no. 4, p. 816-821.

Received: 20 October 2011 Accepted: 21 March 2013 